\title{
Penguatan Kapasitas Petugas Kesehatan Dalam Mengaplikasikan Terapi Komplementer Pasien Tuberkulosis Paru
}

\author{
Hesti Platini, Sandra Pebrianti, Kosim \\ Fakultas Keperawatan, Universitas Padjadjaran \\ Email: hesti13001@unpad.ac.id
}

\begin{abstract}
Abstrak
Petugas kesehatan merupakan seseorang yang berperan aktif dalam meningkatkan derajat kesehatan diantaranya kasus tuberkulosis paru. Petugas kesehatan bukan hanya sebagai rujukan kesehatan tetapi harus mengetahui mengenai dasar dari terapi selain farmakologi untuk menangani masalah yang menyangkut penyakit tuberkulosis paru. Tujuan kegiatan ini yaitu untuk meningkatkan pengetahuan dalam penguatan kapasitas petugas kesehatan untuk mengaplikasikan terapi komplementer dalam mengatasi mual dan muntah pada pasien tuberkulosis paru di wilayah kerja Puskesmas Pasundan Garut. Metode kegiatan ini yaitu pendidikan kesehatan kepada petugas kesehatan berupa pelatihan terapi komplementer untuk mengatasi mual dan muntah pada pasien tuberkulosis paru. Kegiatan ini dimulai dari tahapan perencanaan, pelaksanaan, evaluasi, hingga penyusunan laporan. Hasil pengukuran pengetahuan yaitu pretest dan posttest. Data kemudian dianalisis dengan nilai mean, dan dependent t-test. Hasil menunjukan rata-rata terdapat peningkatan pengetahuan setelah dilakukan pelatihan dengan skor sebelum pelatihan $64,44(\mathrm{SD}=21,15)$; dan rata-rata skor setelah dilakukan pelatihan $82,00(\mathrm{SD}=13,02)$ dengan rata-rata peningkatan skor $17,72(\mathrm{SD}=21,11)$ dan nilai $\mathrm{p}=0,000$. Dengan kegiatan ini pengetahuan petugas kesehatan dapat meningkat dalam mengaplikasikan terapi komplementer untuk mengatasi mual dan muntah pada pasien tuberkulosis paru.
\end{abstract}

Kata kunci: Petugas kesehatan, terapi komplementer, tuberkulosis paru.

\begin{abstract}
Health workers are someone who an active role in improving health status, including cases of pulmonary tuberculosis. Health workers are not only a health reference but must know about the basis of therapy nonpharmacology to deal with problems involving pulmonary tuberculosis. The purpose of this activity is to increase knowledge in strengthening the capacity of health workers to apply complementary therapy to overcome nausea and vomiting in pulmonary tuberculosis patients in the work area of Puskesmas Pasundan Garut. The method in this activity was health education to health workers in the form of training applying complementary therapy to treat nausea and vomiting in patients with pulmonary tuberculosis. This activity starts from the stages of planning, implementation, evaluation, and preparation of reports. The measurement results of knowledge was pretest and posttest. Data was analyzed by means, and dependent t-test. The results was showed an average increase in knowledge after training with scores before training $64.44(S D=21,15)$; and the average score after training was $82.00(S D=13.02)$ with an average score increase of $17.72(S D=$ $21,11)$ and a value of $p=0,000$. With this activity the knowledge of health workers can increase in applying complementary therapies to treat nausea and vomiting in patients with pulmonary tuberculosis.
\end{abstract}

Key words: Complementary Therapy, Healthworker, Pulmonary Tuberculosis. 
Hesti Platini: Penguatan Kapasitas Petugas Kesehatan Dalam Mengaplikasikan Terapi Komplementer

\section{Pendahuluan}

Kasus tuberkulosis terbanyak yaitu di provinsi Jawa Barat dengan provorsi kasus tuberkulosis terbanyak menurut kelompok umur 25-34 tahun sebesar 18,07\%. Diperkirakan 75\% pasien tuberkulosis paru adalah kelompok usia produktif yaitu antara usia 15 sampai 50 tahun (Ditjen P2PL Kemenkes RI [Direktur Jenderal Pengendali Penyakit dan Penyehatan Lingkungan Kementrian Kesehatan Republik Indonesia], 2017). Tuberkulosis secara ekonomi dapat menurunkan produktivitas penderita, selain itu tuberkulosis dapat menimbulkan stigma buruk di masyarakat. Penyebab utama permasalahan tuberkulosis meningkat yaitu adanya kegagalan program tuberkulosis seperti kurang memadainya tata laksana kasus tuberkulosis paru yang diantaranya diagnosis serta panduan obat yang tidak standar, gagal penyembuhan kasus tuberkulosis paru yang telah (Ditjen P2PL Kemenkes RI [Direktur Jenderal Pengendali Penyakit dan Penyehatan Lingkungan Kementrian Kesehatan Republik Indonesia], 2011).

Mengatasi mual dan muntah pada pasien tuberkulosis paru akibat efek obat yang banyak dilakukan yaitu dengan obat anti mual. Akan tetapi hal tersebut berdampak pada gangguan fisiologis dan penurunan keefektifan obat tuberkulosis, maka perlu dilakukan upaya untuk mengatasi efek buruk pemberian farmakologi yaitu dengan intervensi non farmakologi. Intervensi non-farmakologi yang dapat dilakukan diantaranya dengan terapi komplementer yaitu dengan sosialisai terapi pendamping seperti terapi komplementer.

Petugas kesehatan merupakan seseorang yang berperan aktif dalam meningkatkan derajat kesehatan. Pada kasus penyakit tuberkulosis paru, kader kesehatan merupakan sasaran yang tepat dalam pelaksanaan program tersebut karena dianggap sebagai rujukan pertama pelayanan kesehatan. Petugas kesehatan merupakan kepanjangan tangan Puskesmas untuk menangani berbagai masalah kesehatan diantaranta TB Paru. Petugas kesehatan bukan hanya sebagai rujukan kesehatan tetapi harus mengetahui mengenai dasar dari terapi selain farmakologi untuk menangani masalah yang menyangkut penyakit tuberkulosis paru. Tujuan kegiatan ini yaitu untuk meningkatkan penguatan kapasitas petugas kesehatan dalam mengaplikasikan terapi komplementer untuk mengatasi mual dan muntah pada passien tuberkulosis paru di wilayah kerja Puskesmas Pasundan Garut.

Terapi komplementer merupakan terapi pendamping medis sebagai terapi non farmakologi. Terapi ini bukan pengganti intervensi medis. Terapi komplementer dapat berupa promosi kesehatan, pencegahan penyakit ataupun rehabilitasi. Sosialisasi mengenai terapi komplementer pada petugas kesehatan merupakan upaya untuk membantu agar memperkuat aplikasi terapi pendamping medis untuk membantu penyembuhan pasien tuberkulosis paru.

Pengenalan terapi komplementer yang dilakukan pada petugas kesehatan ini ditekankan pada terapi pikiran tubuh dan terapi manipulative. Diantaranya pengenalan terapi dengan pendekatan sosial, perilaku, psikologis, dan spiritual untuk kesehatan serta pengenalan dukungan kelompok. Dalam hal ini petugas kesehatan yang terlibat diantaranya terutama perawat. Terapi komplementer 
Hesti Platini: Penguatan Kapasitas Petugas Kesehatan Dalam Mengaplikasikan Terapi Komplementer

merupakan terapi pendamping medis sebagai terapi non framakologi. Terapi komplementer bukan pengganti medis, akan tetapi sebagai pendamping selain farmakologi. Terapi komplementer membantu proses penyembuhan suatu penyakit atau keluhan. Terapi ini diantaranya terapi pikiran tubuh (mind body therapies), terapi berbasis biologi (biologically based therapies), terapi manipulatif dan berbasis tubuh (manipulative and body based therapies), terapi energi yang termasuk dalam katagori energi hayati dan bioelektromagnetik (energy and biofield therapies).

Kegiatan program pengabdian masyarakat (PPM) ini dilakukan secara terintegrasi dengan Kuliah Kerja Nyata Mahasiswa (KKNM). KKNM ini menjadi suatu bentuk pendidikan dengan cara memberikan pengalaman belajar kepada mahasiswa di tengah-tengah kehidupan masyarakat, dengan secara nyata turut membantu memecahkan masalah masyarakat berdasarkan kompetensi keilmuan masing-masing peserta KKNM terintegrasi. Kompentensi disesuaikan dengan situasi, kondisi, masalah, dan prioritas kebutuhan masyarakat di lapangan dengan pendekatan interdisipliner dan ilmiah. KKNM pada dasarnya merupakan wujud aktivitas Tri Dharma Perguruan Tinggi yang pada praktiknya memotivasi masyarakat kearah peningkatan berswadaya, gotong royong, self planning, self action, self evaluation dalam upaya pembangunan daerah, desa, atau kelurahannya maupun pendidikan warga desa. Target dari kegiatan pengabdian masyarakat ini yaitu salah satunya bentuk aplikasi untuk meningkatkan kesehatan masyarakat. Pendekatan yang dilakukan melalui petugas kesehatan sebagai kepanjangan tangan dalam meningkatkan derajat kesehatan terutama pada penderita tuberkulosis paru agar program pengobatan tuberkulosis paru berhasil dengan menerapkan aplikasi komplementer seperti petugas kesehatan yang berwenang.

Kegiatan pengabdian masyarakat ini diantaranya dilakukannya sebagai penguatan kapasitas petugas kesehatan dalam mengaplikasikan terapi komplementer untuk mengatasi mual dan muntah pada pasien tuberkulosis paru. Kegiatan ini berupa pendidikan kesehatan mengenai terapi komplementer pada petugas kesehatan dengan cara memberikan pelatihan, selama ini tidak banyak petugas kesehatan mengetahui mengenai terapi pendamping medis. Petugas kesehatan lebih berfokus pada pengobatan farmakologi jika ada masalah kesehatan pada masyarakat ataupun pasien. Untuk itu dilakukan penyuluhan dan pengenalan terapi komplementer yang di khususkan untuk mengatasi masalah pada pasien tuberkulosis paru. Pendekatan dimulai dengan survey lokasi untuk mengetahui adanya permasalahan pada warga di area kerja Puskesmas Pasundan, sehingga adanya gambaran untuk dapat diaplikasikannya terapi komplementer. Aplikasi kegiatan ini berawal dari warga atau penderita tuberkulosis paru yang mengeluhkan mual dan muntah karena pengobatan, sehingga terputusnya rejimen obat karena penangan mual muntah seringkali. Selama ini penatalaksanaanya dengan faramakologi. Beberapa petugas belum mngetahui mengenai terapi komplementer untuk mengatasi keluhan tersebut. Sehingga dilakukan pelatihan sebagai penguatan kapasitas petugas untuk mengaplikasikan terapi komplementer untuk mengatasi mual dan muntah. 
Hesti Platini: Penguatan Kapasitas Petugas Kesehatan Dalam Mengaplikasikan Terapi Komplementer

\section{Metode}

Kegiatan ini berupa pendidikan kesehatan melalui pelatihan petugas kesehatan dalam mengaplikasikan terapi komplementer untuk mengatasi mual dan muntah pada pasien tuberkulosis paru. Karena berdasarkan hasil pendahuluan petugas kesehatan beberapa diantaranya belum mengenal terapi pendamping medis seperti terapi komplementer untuk mengatasi mual muntah pasien tuberkulosis paru. Petugas kesehatan lebih banyak memberikan terapi farmakologi dalam menangani mual dan muntah pasien tuberkulosis paru tersebut. Jumlah peserta yang diundang yaitu sebanyak 30 orang petugas kesehatan dan 5 orang kader. Selain itu dalam kegiatan ini diikuti oleh 10 orang mahasiswa yang terintegrasi dengan program kuliah kerja nyata mahasiswa (KKNM) Universitas Padjadjaran yang terintegrasi. Kegiatan ini dimulai dari tahap perencanaan, pelaksanaan, dan evaluasi. Kegiatan ini dilakukan dengan kordinasi dengan pihak Puskesmas, aparat desa untuk menyepakati tujuan, waktu dan tempat pelaksanaan.

Kegiatan ini dilakukan beberapa sesi, diantaranya diskusi, peningkatan pemahaman mengenai materi terapi komplementer dan evaluasi kegiatan. Sebelum dan sesudah kegiatan dilakukan pre-test dan post-test. Kegiatan dipimpin oleh fasilitator dan pemateri, perlengkapan dalam kegiatan ini diantaranya laptop dan LCD proyektor sebagai media visual. Kegiatan dikahiri dengan pemberian door price dan pemberian plakat. Setiap peserta diberikan modul pelatihan sebagai bahan pembelajaran. Untuk menguji signifikansi kegiatan ini maka dilakukan pengukuran pengetahuan dengan menggunakan kuesioner pretest dan posttest. Hasilnya data kemudian dianalisis dengan nilai mean, dan dependent t-test.

\section{Hasil}

Kegiatan ini mendapatkan apresiasi yang baik serta positif. Petugas kesehatan terutama perawat antusias mengikuti program ini . Kegiatan dilakukan dengan sharing informasi dengan tahapan pemberian materi dan brainstorming. Hal yang pertama dilakukan yaitu diskusi dan penyampaian materi, kemudian bertukar pendapat dengan petugas kesehatan.

Tabel 1 Pengetahuan Petugas Kesehatan Tentang Terapi Komplementer dalam Mengatasi Mual dan Muntah pada Pasien Tuberkulosis Paru

\begin{tabular}{llllc}
\hline $\begin{array}{l}\text { Pengetahuan Petugas } \\
\text { Kesehatan dan } \\
\text { Kader Kesehatan }\end{array}$ & Rata-rata & Standar Deviasi & $\begin{array}{l}\text { Nilai Minimum dan } \\
\text { Maksimum }\end{array}$ & Nilai p \\
\hline Sebelum & 64,44 & 21,15 & $20,00-90,00$ & $0,000^{*}$ \\
\hline Sesudah & 82,00 & 13,02 & $40,00-90,00$ & \\
\hline
\end{tabular}

*bermakna $\alpha<0,05$

Tabel 1 menunjukan rata-rata skor pengetahuan petugas kesehatan dan kader kesehatan sebelum dilakukan pelatihan adalah $64,44(\mathrm{SD}=21,15)$; rata-rata skor pengetahuan petugas kesehatan dan 
Hesti Platini: Penguatan Kapasitas Petugas Kesehatan Dalam Mengaplikasikan Terapi Komplementer

kader kesehatan setelah dilakukan kegiatan adalah $82,00(\mathrm{SD}=13,02)$ dengan rata-rata peningkatan skor $17,72(\mathrm{SD}=21,11)$ dan nilai $\mathrm{p}=0,000$.

\section{Pembahasan}

Kegiatan pengabdian kepada masyarakat dengan tema "Penguatan Kapasitas Petugas Kesehatan dalam Mengaplikasikan Terapi Komplementer untuk Mengatasi Mual dan Muntah pada Pasien Tuberkulosis Paru” telah selesai dilaksanakan pada tanggal 3 Juni tahun 2018. Jumlah peserta yang hadir yaitu sebanyak 35 orang. Tujuan penguatan kapaitas petugas kesehatan ini yaitu untuk mensosialisasikan salah satu terapi pendamping medis untuk mengatasi keluhan mual dan muntah pada pasien tuberkulosis paru. Petugas kesehatan merupakan kepanjangan tangan warga masyarakat di Puskesmas ataupun Rumah Sakit. Kegiatan ini terintegrasi dengan KKNM (Kuliah Kerja Nyata Mahasiswa) Universitas Padjadjaran, sehingga mahasiswa terlibat dan secara nyata mengikuti kegiatan pengabdian masyarakat ini. Peran mahasiswa KKN sangat membantu terlaksananya kegiatan ini, selain pengalaman baru, kolaborasi ini dapat terjalin kerjasama tim yang baik. Dalam melaksanakan KKN di Kabupaten Garut.

Hasil kegiatan ini terdapat peningkatan pengetahuan pada petugas kesehatan dalam mengaplikasikan terapi komplementer. Peningkatan pengetahuan ini adalah upaya dalam meningkatkan derajat kesehatan masyarakat terutama sebagai penggerak dalam penanggulangan tuberkulosis paru. Dengan terpaparnya terapi komplementer pada petugas kesehatan, maka upaya pencegahan putus obat pada penderita tuberkulosis paru dapat diatasi. Sasaran yang tepat sebagai penguatan kapasitas petugas kesehatan dalam perannya untuk meningkatkan derajat kesehatan. Kegiatan ini dilatarbelakangi adanya warga masyarakat yang menderita tuberkulosis paru dengan keluhan mual dan muntah, beberapa diantaranya dropout pengobatan. Peningkatan pengetahuan petugas kesehatan mempengaruhi keberhasilan pengobatan tuberkulosis paru, terutama dapat membantu mengurangi keluhan penderita tuberkulosis paru seperti mual dan muntah dengan terapi non farmakologis. Kegiatan pelatihan ini diantaranya pmeberian informasi. Informasi akan memberikan pengaruh pada pengetahuan seseorang menjadi lebih meningkat melalui penyampaian informasi dari berbagai media (Hendra, 2008).

Peningkatan pengetahuan petugas kesehatan setelah pelatihan pada kegiatan ini dapat menjadikan peran petugas tersebut berubah kearah lebih baik. Peran petugas kesehatan bukan hanya memberikan informasi pada penderita tuberkulosis paru, tetapi dapat mengaplikasikan secara langsung perannya menerapkan bantuannya melalui terapi komplementer untuk keberhasilan penanggulangan program tuberkulosis paru. Sesuai dengan penelitian Has, Efendi Ulfiana dan Makhfuldi (2014) bahwa petugas kesehatan setelah mengikuti pelatihan mengenai konseling 
Hesti Platini: Penguatan Kapasitas Petugas Kesehatan Dalam Mengaplikasikan Terapi Komplementer

tuberkulosis paru memiliki pengetahuan yang baik dengan sikap yang positif dan sebagian besar memiliki keterampilan yang baik.

Peran petugas kesehatan sangat berpengaruh terhadap pelaksanaan program promosi kesehatan pada pasien tuberkulosis paru. Penelitian Yuniarti, Shaluhiyah dan Widjanarko (2012) menunjukan bahwa variabel yang penting berhubungan dengan kinerja petugas penyuluh kesehatan salah satunya pendidikan, pelatihan dan pengetahuan. Walaupun pada penelitian ini yang paling berpengaruh adalah tingkat pendidikan pada petugas kesehatan. Untuk itu kegiatan ini merupakan salah satu bentuk pelatihan dan peningkatan pengetahuan pada petugas kesehatan dalam upaya meningkatkan derajat kesehatan melalui metode terapi komplementer. Mengaplikasikan terapi komplementer dapat membantu penatalaksanaan medis. Pelatihan petugas kesehatan ini terutama pemegang program tuberkulosis paru dapat meningkatkan cakupan dan penatalaksaan program penanggulangan tuberkulosis. Sesuai dengan penelitian Hariadi dan Iswanto (2009) bahwa variabel yang terkait dengan hubungan petugas Puskesmas dengan cakupan penderita tuberkulosis yaitu keterampilan staf.

Terapi komplementer banyak didukung teori-teori, dan dapat digunakan sebagai intervensi oleh perawat (Widyatuti, 2008). Dalam hal ini petugas kesehatan terutama pemegang program tuberkulosis sebagai penyampai informasi dan setelah mengetahui terapi komplementer dapat diaplikasikan secara langsung pada penderita tuberkulosis paru. Keberhasilan dalam peningkatan angka kesembuhan penderita tuberkulosis paru bukan hanya pada penderita saja, akan tetapi peran aktif petugas kesehatan. Jika petugas kesehatan berpendidikan tinggi, akan tetapi kurang aktif mengikuti pertemuan mengenai tuberkulosis, makan menyebabkan keaktifan yang rendah (Ayulestari, Thaha, \& Arsyad, 2011). Pengetahuan petugas dapat ditingkatkan melalui pertemuan seperti lokakarya ataupun pelatihan. Menurut Notoatmodjo (2011) bahwa pengetahuan merupakan domain perilaku dimana suatu tindakan dipengaruhi oleh pengetahuan. Kegiatan pelatihan ini merupakan penyampaian informasi untuk penguatan kapasitas petugas kesehatan dalam menerapkan terapi komplementer, hal ini terbukti dari hasil pretest dan posttest. Terapi komplementer sudah tertulis dan dapat dilakukan di Indonesia sesuai dengan permenkes RI Nomor 1109/PER/IR/2007 tentang penyelenggaraan pengobatan alternatif di fasilitas kesehatan.

Hasil pendidikan kesehatan dengan pelatihan dalam penguatan kapasitas petugas kesehatan ini menunjukan adanya peningkatan pengetahuan antara sebelum dan setelah pelatihan. Hal ini dapat memaksimalkan kinerja petugas kesehatan untuk menjalankan perannya dengan baik. Walaupun berbeda dengan penelitian Trisna dan Ilyas (2017) bahwa tidak terdapat hubungan antara pelatihan pada petugas pemegang tuberkulosis dengan pelatihan terhadap kinerja pemegang program tuberkulosis. Pengetahuan merupakan pemahaman lisan mengenai apa yang diketahui dari suatu pengalaman maupun proses belajar. Apabila pengetahuan baik maka petugas memiliki pengetahuan yang baik tentang pekerjannya (Setyowati, Saraswati, Adi, 2018). Hasil menunjukan bahwa 
Hesti Platini: Penguatan Kapasitas Petugas Kesehatan Dalam Mengaplikasikan Terapi Komplementer

pelatihan ini dapat meningkatkan penguatan kapasitas petugas kesehatan dalam mengaplikasikan terapi komplementer untuk mengatasi mual dan muntah pada pasien tuberkulosis paru. Indikatornya terdapat perubahan dari segi pengetahuan petugas kesehatan. Pengetahuan petugas kesehatan berkaitan erat dengan terpaparnya informasi mengenai penatalaksanaan yang efektif pada pasien tuberkulosis paru dengan keluhan. Petugas kesehatan harus memiliki pengetahuan yang baik untuk mengaplikasikan keterampilan pengetahuan mengenai terapi komplementer pada pasien tuberkulosis paru.

Pengenalan terapi komplementer pada petugas kesehatan mengenai terapi komplementer secara umum maupun dalam mencegah mual dan muntah untuk pasien tuberkulosis paru merupakan salah satu bentuk peningkatan pengetahuan karena mudah dilakukan dan besar manfaatnya. Terutama dapat meningkatkan peran aktif penanggulangan tuberkulosis serta pengetahuan mengenai terapi non farmakologi pada petugas kesehatan terutama pemegang program tuberkulosis dalam mengatasi keluhan penderita tuberkulosis.

\section{Simpulan}

Hasil menunjukan rata-rata terdapat peningkatan pengetahuan setelah dilakukan pelatihan pada petugas kesehatan. Dengan kegiatan ini pengetahuan petugas kesehatan dapat meningkat dalam mengaplikasikan terapi komplementer untuk mengatasi mual dan muntah pada pasien tuberkulosis paru. Untuk itu perlu dilakukan pendidikan kesehatan yang serupa dengan tema yang berbeda pada program lain sebagai optimalisasi peran petugas. Peningkatan pengetahuan petugas kesehatan mempengaruhi keberhasilan pengobatan tuberkulosis paru, terutama dapat membantu mengurangi keluhan penderita tuberkulosis paru seperti mual dan muntah dengan pendekatan terapi komplementer. Peran petugas kesehatan tidak hanya penatalaksanaan farmakologi saja tetapi terapi non farmakologi untuk diaplikasikan. Sehingga meningkatkan penguatan kapasitas petugas kesehatan dalam mengaplikasikan terapi komplementer dalam mencegah mual dan muntah pada pasien tuberculosis.

\section{Ucapan Terima kasih}

Penulis menyampaikan terima kasih sebesar-besarnya kepada semua pihak yang telah membantu kegiatan Program Pengabdian pada Masyarakat ini. Kegiatan ini mendapatkan pendanaan dari hibah riset internal Universitas Padjadjaran (HIU UNPAD). Penulis ucapkan terima kasih kepada Prof. Dr. Med. Tri Anggono Achmad, dr., selaku rektor Universitas Padjadjaran, kepada $\mathrm{Hj}$. Henny Suzan Mediani, S.Kp., MNg., Ph.D selaku Dekan Fakultas Keperawatan Unversitas Padjadjaran, kepada Kusman Ibrahim, Ph.D selaku Kepala Departemen Medikal Bedah fakultas keperawatan Universitas Padjadjaran atas kesempatan dan dukungan yang telah diberikan dalam melaksanakan program ini. Penulis sampaikan terima kasih kepada Puskesmas Pasundan Garut serta petugas kesehatan atas 
Hesti Platini: Penguatan Kapasitas Petugas Kesehatan Dalam Mengaplikasikan Terapi Komplementer

partisipasi dalam kegiatan ini, kepada warga desa Sukanegla atas partisipasinya dan keterlibatnnya dalam kegiatan ini. Penulis ucapkan terima kasih kepada mahasiswa KKNM yang membantu terlaksananya kegiatan ini. Pelaksanaan kegiatan ini banyak kendala yang ditemukan. Namun, berkat bantuan dan kerja sama yang baik dari berbagai pihak, segala kesulitan dapat diselesaikan tanpa permasalahan berarti. Semoga Allah membalas semua kebaikan.

\section{Daftar Pustaka}

Mar'ah Has, E. M., Efendi, F., Ulfiana, E., \& Makhfudli, M. (2014). Peningkatan Pengetahuan, Sikap, dan Ketrampilan Petugas Kesehatan dalam Pelaksanaan Konseling Efektif TB Paru di Puskemas. Jurnal Sumber Daya Manusia Kesehatan, 1(1).

Hariadi, E., \& Iswanto, R. A. A. (2009). Hubungan Faktor Petugas Puskesmas dengan Cakupan Penderita Tuberkulosis Paru BTA Positif. Berita Kedokteran Masyarakat, 25(4), 189.

Hendra, AW. (2008). Faktor-Faktor Yang Mempengaruhi Pengetahuan, Jakarta : Pustaka Sinar Harapan Indonesia, K. K. R. (2014).

Pedoman nasional pengendalian tuberkulosis. Direktorat Jendral Pengendalian Penyakit Dan Penyehatan Lingkungan, Jakarta, Indonesia, ISBN, 978-979.

Notoatmodjo, S. (2010). Promosi Kesehatan Teori dan Aplikasi. Jakarta: Rineka Cipta.

Penyakit, D. J. P., \& Lingkungan, P. (2011). Kementerian Kesehatan Republik Indonesia. Pedoman nasional pengendalian tuberculosis. Jakarta: Kementerian Kesehatan Indonesia, 6.

Setyowati, I., Saraswati, L. D., \& Adi, M. S. (2018). Gambaran Faktor-Faktor Yang Terkait Dengan Kinerja Petugas Dalam Penemuan Kasus pada Program Tuberkulosis Paru Di Kabupaten Grobogan. Jurnal Kesehatan Masyarakat (e-Journal), 6(1), 264-272.

Trisna, E., \& Ilyas, H. (2017). Analisa Faktor-Faktor yang Berhubungan Dengan Kinerja Perawat Dalam Penatalaksanaan Tuberkulosis. Jurnal Keperawatan, 9(1), 71-78.

Yuniarti, Y., Shaluhiyah, Z., \& Widjanarko, B. (2012). Kinerja Petugas Penyuluh Kesehatan Masyarakat dalam Praktek Promosi Kesehatan di Dinas Kesehatan Kabupaten Pati. The Indonesian Journal of Health Promotion (Jurnal Promosi Kesehatan Indonesia), 7(2), 165173.

Widyatuti, W. (2008). Terapi komplementer dalam keperawatan. Jurnal Keperawatan Indonesia, 12(1), 53-57. 